\title{
Insulin Prescription Charts at a University Hospital: High Variability of Design Characteristics
}

\author{
Julia Kopanz ${ }^{1 *}$, Katharina M Neubauer ${ }^{1}$, Gerald Sendlhofer ${ }^{2,3}$, Barbara Semlitsch', Andreas Pak ${ }^{4}$, Thomas R Pieber ${ }^{1}$, \\ Johannes Plank ${ }^{5}$
}

From Safety in hospitals: from strategy to implementation Annual Scientific Meeting 2015

Graz, Austria. 29-30 September 2015

\section{Background}

Diabetes mellitus exists in approximately $10 \%$ of hospitalized patients and hyperglycemia arises in 32 to $38 \%$ of patients in community hospitals [1-3]. Hyperglycemia is associated with increased morbidity, mortality and hospital costs, regardless of whether a hospitalized patient has a known history of diabetes or not $[1,4]$.

Insulin has frequently been reported to be in the list of top 10 high alert medicines worldwide. The subcutaneous insulin prescribing chart provides a common tool for consistent communication, documentation, interpretation and administration of insulin orders. Evidence indicates that outcomes and safety can be compromised when significant variations in patient care exist [5]. Our objective was to evaluate the quality of design characteristics of subcutaneous insulin prescription charts at a University Hospital.

\section{Materials and methods}

The University Hospital Graz (Austria) consists of 14 adult inpatient departments with 39 general wards. In the past, subcutaneous insulin prescription charts were mainly developed on an individual base by each ward. We collected the currently used subcutaneous insulin prescription charts from all wards from the $1^{\text {st }}$ of April 2015 to the $1^{\text {st }}$ of June 2015 , and analyzed them regarding quality parameters, accordance to international and local standards $[6,7]$.

\section{Results}

20 different charts for in-hospital insulin prescription are currently used at the 39 wards at the University Hospital.

\footnotetext{
* Correspondence: julia.kopanz@medunigraz.at

'Department of Internal Medicine, Division of Endocrinology and

Metabolism, Medical University of Graz, Graz, Austria

Full list of author information is available at the end of the article
}

Out of these, 8 are designed for documentation of subcutaneous insulin prescription only and 5 allow combined documentation of insulin and other forms of antihyperglycemic therapy. 3 charts are designed to closely (hourly) monitor various vital parameters and 4 charts document insulin therapy combined with the general inpatient medication charts. Selected quality parameters of insulin prescription charts are presented in table 1.

\section{Conclusion}

A distinct variability in design characteristics of insulin prescription charts was found at the University Hospital Graz. This heterogeneity increases the already prevalent complexity of insulin therapy and glycemic management in hospitalized patients. Thus, standardization of a subcutaneous insulin prescribing chart across the wards with guidance including support for correction-schedule may impact the quality of patient care and safety.

\section{Competing interests \\ There are no competing interests.}

\section{Acknowledgements}

The authors thank all the participating departments for collaboration and acknowledge Lydia Jantscher for questionnaire analysis.

\section{Authors' details}

${ }^{1}$ Department of Internal Medicine, Division of Endocrinology and Metabolism, Medical University of Graz, Graz, Austria. ${ }^{2}$ Department of Quality and Risk Management, University Hospital Graz, Graz, Austria. ${ }^{3}$ Division of Plastic, Aesthetic and Reconstructive Surgery, Department of Surgery, Medical University of Graz, Graz, Austria. ${ }^{4}$ Department of Controlling, University Hospital Graz, Graz, Austria. ${ }^{5}$ Department of Internal Medicine, Division of Gastroenterology and Hepatology, Medical University of Graz, Graz, Austria.

Published: 30 October 2015 
Table 1 Quality parameters of 20 currently used insulin prescription charts [n (\%)]

\begin{tabular}{|c|c|c|}
\hline Marked space provided for: & & Yes, $\mathrm{n}(\%)$ \\
\hline \multirow[t]{7}{*}{ Patient Identification and Characteristics } & patient identification label & $10(50)$ \\
\hline & name & $9(45)$ \\
\hline & declaration of ward & $10(50)$ \\
\hline & no label, no name & $2(10)$ \\
\hline & type of diabetes & $1(5)$ \\
\hline & $\mathrm{HbA} 1 \mathrm{c}^{\mathrm{a}}$ & $7(35)$ \\
\hline & $\mathrm{BMI}^{\mathrm{b}}$ or body weight/height & $8(40)$ \\
\hline \multirow[t]{9}{*}{ Treatment Issues } & Adequate documentation of insulin therapy possible? & $9(45)$ \\
\hline & Ordering of $\mathrm{bg}^{\mathrm{c}}$ sampling frequency per day possible? & $0(0)$ \\
\hline & Identification of prescribing physician (initials) possible? & $2(10)$ \\
\hline & Identification of insulin administering nurse (initials) possible? & $5(25)$ \\
\hline & Is a bgc target range predefined? & $0(0)$ \\
\hline & Is a hypoglycemic range predefined? & $0(0)$ \\
\hline & Is a hyperglycemic range predefined? & $0(0)$ \\
\hline & Documentation for correctional insulin for hyperglycemia possible? & $2(10)$ \\
\hline & Documentation for hypoglycemic treatment possible? & $0(0)$ \\
\hline
\end{tabular}

\footnotetext{
${ }^{\mathrm{a}}$ glycated hemoglobin. ${ }^{\mathrm{b}}$ body mass index. ${ }^{\mathrm{c}}$ blood glucose.
}

\section{References}

1. Umpierrez GE, Hellman R, Korytkowski MT, Kosiborod M, Maynard GA, Montori VM, et al: Management of Hyperglycemia in Hospitalized Patients in Non-Critical Care Setting: An Endocrine Society Clinical Practice Guideline. J Clin Endocrinol Metab 2012, 97(1):16-38.

2. Rayman G, Service NH: National Diabetes Inpatient Audit 20132014 [http:// www.hscic.gov.uk/catalogue/PUB13662/nati-diab-inp-audi-13-nat-rep.pdf], accessed June-11-2015.

3. Umpierrez GE, Isaacs SD, Bazargan N, You X, Thaler LM, Kitabchi AE: Hyperglycemia: An Independent Marker of In-Hospital Mortality in Patients with Undiagnosed Diabetes. I Clin Endocrinol Metab 2002, 87(3):978-982.

4. Schmeltz $L R$, Ferrise C: Glycemic Management in the Inpatient Setting Hosp Pract (1995) 2012, 40(2):44-55.

5. Christofidis MJ, Horswill MS, Hill A, McKimmie BM, Visser T, Watson MO: Task Analysis and Heuristic Analysis of Insulin Charts: Final report prepared for the Australian Commission on Safety and Quality in Health Care: 2 February 2012. [http://www.safetyandquality.gov.au/wp-content/ uploads/2012/06/56679-Insulin-charts-heuristic-analysis-2-Feb-2011-FinalReport.pdf], accessed June-11-2015] accessed June-11-2015.

6. National Diabetes Inpatient Audit. Hospital Characteristics Questionnaire. 2013 [http://www.hscic.gov.uk/diabetesinpatientaudit], accessed June-11-2015.

7. National Diabetes Inpatient Audit. Bedside Audit Questionnaire. 2013 [http://www.hscic.gov.uk/diabetesinpatientaudit], accessed June-11-2015.

Cite this article as: Kopanz et al:: Insulin Prescription Charts at a

University Hospital: High Variability of Design Characteristics. Safety in Health 2015 1(Suppl 1):A21.

\section{Submit your next manuscript to BioMed Central and take full advantage of:}

- Convenient online submission

- Thorough peer review

- No space constraints or color figure charges

- Immediate publication on acceptance

- Inclusion in PubMed, CAS, Scopus and Google Scholar

- Research which is freely available for redistribution

Submit your manuscript at www.biomedcentral.com/submit
C Biomed Central 